\title{
THE PARADIGM OF THEO-ANTHROPO-COSMOCENTRISM: Reposition of the Cluster of Non-Islamic Studies in Indonesian State Islamic Universities
}

\author{
Toto Suharto \\ Institut Agama Islam Negeri (IAIN) Surakarta \\ e-mail: tosuh71@gmail.com
}

\begin{abstract}
State Islamic Universities (UIN) in Indonesia nowadays has developed their study courses by opening the faculty of social science and humanities and the faculty of the natural science. This development is constitutionally "has gone beyond" scientific mandate of UIN, which only had the authority to execute the education in the cluster of religious sciences. Applying the approach of philosiphy of knowledge, this paper tried to commit the reposition the sciences of non Islamic studies cluster in UIN so that there is no gap between the two clusters, by offering the application of the paradigm of theo-antropo-cosmosentrism. Applying content analysis on texts related to the theme of the study, this paper offered the integration model of "Triangle of Science" which is based on the paradigm of Theo-anhropo-cosmosentrism. This paradigm tried to integrate the paradigms of theocentrism, anthropocentrism and cosmocentrism.

Universitas Islam Negeri (UIN) di Indonesia dewasa ini telah mengembangkan wilayah studi Islamnya dengan membuka fakultas dalam ilmu-ilmu sosialhumaniora dan ilmu-ilmu kealaman. Perkembangan ini secara konstitusional telah "melampaui batas" mandat keilmuan UIN, yang hanya diberi kewenangan untuk menyelenggarakan pendidikan dalam rumpun ilmu agama. Tulisan ini dengan pendekatan filsafat ilmu mencoba mereposisi ilmu-ilmu non-rumpun ilmu agama yang ada di UIN, sehingga tidak terjadi gap antar keduanya, dengan menawarkan penggunaan paradigma teo-antropo-kosmosentrisme. Dengan analisis isi terhadap teks-teks yang terkait dengan tema kajian, tulisan ini menawarkan model integrasi "Segitiga Ilmu" yang berbasiskan pada paradigma teo-antropo-kosmosentrisme. Paradigma ini mencoba mengintegrasikan antara paradigma teosentrisme, antroposentrisme dan kosmosentrisme.
\end{abstract}

Keywords: UIN, reposition, paradigm, theo-anthropo-cosmosentrism 


\section{A. Pendahuluan}

A. Mukti Ali, mantan Menteri Agama RI, dalam sebuah ceramah ilmiah yang disampaikannya pada Rakernas Perguruan Tinggi Muhammadiyah (PTM) tahun 1986 pernah menyatakan bahwa ada tiga elemen yang harus diketahui dalam Islam, yaitu Tuhan, manusia dan alam. Ketiga elemen ini merupakan elemen pokok yang dibahas dalam Islam dan agama-agama lain. Hubungan antara ketiga masalah ini merupakan hal yang penting. Oleh karena itu, hingga sekarang, ketiga persoalan besar ini senantiasa dikaji oleh pikiran-pikiran orang modern. Ada yang mencoba mengkaji ketiganya dengan perspektif saintis, ada yang melihatnya dari kacamata filosofis, dan ada pula yang meninjaunya dari perspektif agama. ${ }^{1}$ Mulyadhi Kartanegara menyebut ketiga persoalan ini sebagai trilogi metafisika, yang dalam sejarah kajian Islam, telah melahirkan filsafat Islam tentang ketuhanan, filsafat Islam tentang kemanusiaan, dan filsafat Islam tentang kealaman. ${ }^{2}$

Bagaimana dengan studi Islam di Indonesia, khususnya di lingkungan Pendidikan Tinggi Keagamaan Islam (PTKI)? Dengan melihat trilogi metafisika ini, studi Islam di Indonesia hingga saat ini dapat dipetakan dalam tiga fase perkembangan. Fase pertama adalah era sebelum 1990. Pada fase ini, studi Islam di Indonesia didominasi oleh corak kajian yang bersifat normatif, karena berpegang pada paradigma "teosentrisme". Dengan paradigma ini, banyak dihasilkan kajian-kajian yang sifatnya normatif-teologis oleh akademisi PTKI, baik dalam bidang tafsir, hadits, fiqih, kalam ataupun tasawuf. Fase kedua adalah masa antara 1990-2000. Pada fase ini, studi Islam telah mengalami perkembangan yang cukup signifikan, dengan mulai bergeser ke arah penggunaan paradigma "antroposentrisme". Hal ini disebabkan telah banyaknya akademisi PTKI yang berhasil menyelesaikan studi S2 dan S3 dari negeri Barat.

Studi Islam pada masa ini tidak lagi bersifat normatif, yang berkutat pada kajian dan telaah tentang tafsir, hadits, fiqih, kalam atau tasawuf. Kajian itu lebih bersifat antroposentris, dengan digunakannya berbagai pendekatan yang diambil dari ilmu-ilmu sosial dan humaniora, mulai dari pendekatan historis,

\footnotetext{
${ }^{1}$ A. Mukti Ali, Metode Memahami Agama Islam, (Jakarta: Bulan Bintang, 1991), h. 25-26.

2Mulyadhi Kartanegara, Menembus Batas Waktu: Panorama Filsafat Islam, Cet. I, (Bandung: Mizan, 2002), h.124.
} 
perbandingan, kontekstual, hingga pendekatan hermeneutis-filosofis. ${ }^{3}$ Fase ketiga adalah masa setelah tahun 2000-an hingga sekarang, yang ditandai dengan lahirnya UIN-UIN di Indonesia. Pada fase ini, PTKI telah membuka kran keilmuan dengan mendirikan fakultas dan program studi kealaman, di samping studi sosial-humaniora yang lebih dulu eksis. Paradigma "kosmosentrisme" pada masa ini sudah mulai diperkenalkan oleh akademisi PTKI, dengan menyelengarakan fakultas seperti sains dan teknologi, ataupun fakultas kedokteran di beberapa UIN.

Namun demikian, catatan penting yang perlu mendapat perhatian serius bagi PTKI dewasa ini adalah adanya kecenderungan penggunaan paradigma antroposentrisme dan atau kosmosentrisme "yang berlebihan", sehingga mengesankan "terabaikannya" pendekatan teosentrisme, terutama untuk kajian Islam di UIN. Kehadiran UIN di Indonesia seyoganya memadukan ketiga paradigma tersebut, bahkan paradigma teosentrisme justru menjadi basis dan core bagi paradigma antroposentrisme dan kosmosentrisme, sehingga melahirkan apa yang disebut paradigma "teo-antropo-kosmosentrisme".

Menyikapi penggunaan paradigma antroposentrisme dan kosmosentrisme yang dikesankan "berlebihan", sehingga sedikit-banyak "mengabaikan" paradigma teosentrisme, kini telah lahir UU No. 12 Tahun 2012 tentang Pendidikan Tinggi. Pasal 10 ayat (2) UU ini menyebutkan bahwa PTKI diberi mandat keilmuan untuk menyelenggarakan pendidikan dalam rumpun ilmu yang disebut "rumpun ilmu agama". Di dalam penjelasan ayat ini dinyatakan mengenai batasan rumpun ilmu agama sebagai berikut:

"Rumpun ilmu agama merupakan rumpun ilmu pengetahuan yang mengkaji keyakinan tentang ketuhanan atau ketauhidan serta teks-teks suci agama, antara lain ilmu ushuluddin, ilmu syariah, ilmu adab, ilmu dakwah, ilmu tarbiyah, filsafat dan pemikiran Islam, ekonomi Islam, ilmu pendidikan agama Hindu, ilmu penerangan agama Hindu, filsafat agama Hindu, ilmu pendidikan

\footnotetext{
3Toto Suharto, "Tren Baru Studi Islam di Indonesia: Menuju Teo-antroposentrisme" dalam Toto Suharto dan Nor Huda (eds.), Arah Baru Studi Islam di Indonesia: Teori dan Metodologi, cet. I, (Yogyakarta: Ar-Ruzz Media, 2008), h. 13-34. Artikel ini mendiskusikan lahirnya beragam pendekatan studi Islam yang digagas ilmuwan PTKIN alumni luar negeri pasca 1980-an hingga tahun 2000. Diakui Hassan Hanafi bahwa studi keislaman (Islamic Studies) sudah saatnya mulai mengalami pergeseran, bergeser dari wilayah studi yang dulunya hanya mengkaji persoalan-persoalan "ilāhiyyat" (teologis), menuju paradigma keilmuan yang lebih menelaah dan mengkaji secara serius persoalan-persoalan "insāniyyat" (antropologis). Baca Hassan Hanafi, Dirasat Islamiyyah, (t.t.p.: Maktabah al-Anglo alMishriyyah, t.th.), h. 205. Lihat juga M. Amin Abdullah, Falsafah Kalam di Era Postmodernisme, cet. II, (Yogyakarta: Pustaka Pelajar, 1997), h. 43.
} 
agama Budha, ilmu penerangan agama Budha, filsafat agama Budha, ilmu pendidikan agama Kristen, ilmu pendidikan agama Katholik, teologi, misiologi, konseling pastoral, dan ilmu pendidikan agama Khong $\mathrm{Hu} \mathrm{Cu."4}$

Berdasarkan UU tersebut, PTKI diberi mandat keilmuan untuk mengkaji rumpun ilmu agama dengan tujuh kategori keilmuan, yaitu: (1) Ilmu Ushuluddin, (2) Ilmu Syariah, (3) Ilmu Adab, (4) Ilmu Dakwah, (5) Ilmu Tarbiyah, (6) Filsafat dan Pemikiran Islam, (7) Ekonomi Islam. Jadi, core bisnis PTKI adalah menyelenggarakan pendidikan hanya dalam tujuh disiplin ilmu keagamaan tersebut. Namun, dalam realitanya, UIN-UIN dewasa ini telah membuka fakultas dan program studi di luar disiplin ilmu keagamaan. Kajian terakhir menunjukkan bahwa UIN-UIN kini telah mulai membuka lima fakultas non-rumpun ilmu agama, yaitu fakultas psikologi, fakultas sains dan teknologi, fakultas kedokteran dan ilmu kesehatan, fakultas ilmu sosial dan ilmu politik, dan bahkan untuk tahun 2014 kemarin ada yang membuka fakultas sumber daya alam dan lingkungan. ${ }^{5}$

Di satu sisi, kelahiran UU No. 12 Tahun 2012 tentang Pendidikan Tinggi, bagaimanapun juga, merupakan "angin segar" bagi dunia PTKI, karena dengan UU ini, status PTKI di Indonesia menjadi jelas keberadaannya, yaitu memiliki basis konstitusional, yang setara dengan pendidikan tinggi umum (PTU). PTKI di Indonesia, baik negeri ataupun swasta, dengan sendirinya dapat menyelenggarakan pendidikan tinggi dengan menjadikan rumpun ilmu agama sebagai wilayah kajiannya. Tidak dapat dibayangkan apabila Pasal 10 UU ini tidak mencantumkan ilmu agama sebagai salah satu rumpun ilmu pengetahuan dan teknologi. Tentunya seluruh PTKI dapat dibubarkan, karena tidak memiliki basis konstitusional dalam penyelenggaraanya. ${ }^{6}$ Sementara pada sisi yang lain, penyelenggaraan pendidikan oleh UIN pun tidak perlu kebablasan dengan menyelanggarakan pendidikan di luar core bisnis keilmuannya. Jadi, dalam konteks ini, terdapat gap antara mandat keilmuan PTKI dalam UU Pendidikan Tinggi dengan realitas keilmuan di UIN. Kesenjangan inilah kiranya yang menjadi kegelisahan akademik tulisan ini, sehingga perlu dilakukan kajian menTinggi.

4Penjelasan pasal 10 ayat (2) huruf (a) Undang-Undang RI No. 12 Tahun 2012 tentang Pendidikan

5Toto Suharto dan Khuriyah, "The Scientific Viewpoint in State Islamic University in Indonesia", Jurnal Pendidikan Islam, Vol. 1, No. 1, Juni 2014 M/1435 H, h. 78.

${ }^{6}$ Toto Suharto, "Studi Islam di Era Multikultural: Respons UIN terhadap Kebijakan Rumpun Ilmu Agama", paper dipresentasikan pada $14^{\text {th }}$ Annual International Conference on Islamic Studies (AICIS), di Grand Senyiur Hotel, Balikpapan, tanggal 21-24 November 2014, h. 3. 
dalam mengenai posisi ilmu-ilmu non-rumpun ilmu agama dalam studi Islam di UIN dewasa ini.

Tulisan ini dengan pendekatan filsafat ilmu bermaksud membongkar epistemologi keilmuan UIN, kemudian mereposisikannya sesuai dengan mandat keilmuan PTKI, sehingga tidak terjadi gap antara keduanya. Dengan analisis isi terhadap teks-teks yang terkait dengan tema kajian, tulisan ini diharapkan menjadi kontribusi ilmiah bagi pengembangan studi Islam di Indonesia, dalam artian studi Islam ini tetap on the track sesuai UU Pendidikan Tinggi. Tawaran yang diberikan tulisan ini adalah memantapkan penggunaan paradigma teoantropo-kosmosentrisme bagi studi Islam di UIN. Paradigma ini mengandaikan terintegrasinya antara paradigma teosentrisme, paradigma antrosposentrisme dan paradigma kosmosentrisme, bahkan paradigma teosentrisme menjadi "payung" bagi dua paradigma lainnya. Untuk itu, paparan berikut mencoba membahas rumun ilmu agama dalam UU Pendidikan Tinggi, epistemologi keilmuan UIN, dan reposisi ilmu-ilmu non-rumpun ilmu agama di UIN dengan menggunakan paradigma teo-antropo-kosmosentrisme.

\section{B. Mandat Keilmuan PTKI Menurut UU Pendidikan Tinggi}

Studi Islam sejatinya merupakan hal yang tidak dapat dipisahkan dari pengembangan kualitas intelektual kaum Muslim itu sendiri. Studi Islam dalam maknanya yang paling luas adalah masalah intelektual. Studi Islam yang mengabaikan dimensi intelektual akan melahirkan kemandulan dan kebangkrutan intelektualisme di kalangan Muslim. ${ }^{7}$ Oleh karena itu, menurut Syafii Maarif, untuk dapat mencapai peningkatan kualitas profesi, seorang Muslim yang melakukan studi Islam harus dapat mendalami bidang spesialisasinya dan disiplin-disiplin terkait. Akan tetapi, untuk dapat mengembangkan visi intelektual, seorang ilmuwan Muslim harus menerobos batas-batas disiplin yang digelutinya. Dia harus dapat menggumuli agama, filsafat, sejarah, sastra dan wacana-wacana intelektual lainnya. Tanpa bantuan komponen ilmu-ilmu ini, visi intelektual studi Islam akan terpasung oleh spesialisasi bidang yang digelutinya. ${ }^{8}$

\footnotetext{
${ }^{7}$ Lihat A. Syafii Maarif, Islam: Kekuatan Doktrin dan Kegamangan Umat, cet. I , (Yogyakarta: Pustaka Pelajar, 1997), h. 34.

${ }^{8}$ A. Syafii Maarif, Islam: Kekuatan Doktrin dan Kegamangan Uma, h. 37.
} 
Kemampuan intelektual Muslim untuk "menerobos" batas-batas disiplin yang digelutinya di era multikultural dewasa ini adalah sebuah keniscayaan, agar tidak mengalami kemandulan dan kebangkrutan intelektual, sebagaimana disinyalir Syafii Maarif di atas. Namun, lagi-lagi penulis ingin menguatkan bahwa kemampuan "menerobos" batas ini secara etis harus juga berpijak pada landasan core keilmuannya. Fazlur Rahman pernah mengingatkan bahwa studi Islam itu harus tetap Qur'an oriented, ${ }^{9}$ artinya segala permasalahan yang ada harus dipelajari dan ditimbang dulu berdasarkan sumber ajaran Islam, yaitu al-Qur'an dan Sunnah. Di sinilah posisi penggunaan paradigma "teosentrisme". Setelah permasalahan itu diberi landasan moral yang solid, barulah kemudian dicarikan kerangka penyelesaiannya dengan telaah yang berdasar pada paradigma "antroposentrisme". Hal ini perlu dilakukan, mengingat "Islam yang tidak dapat memecahkan problem-problem kemanusiaan hanya akan menjadi ancaman di masa depan",10 demikian tulis Rahman. Untuk itu, masalah-masalah kemanusiaan itu diselesaikan dengan paradigma "teo-antroposentrisme". Akan tetapi, persoalan global saat ini bukan hanya menyangkut kemanusiaan, tapi juga terkait dengan persoalan kealaman, seperti masalah pemanasan global, pelestarian lingkungan, dan lain-lain, sehingga perlu juga studi Islam mengkaji masalah kosmosentrisme ini dengan tidak melepasnya dari akar teosentrismenya.

Untuk "membingkai" studi Islam yang menjadi core bisnis PTKI itu, Pemerintah dengan persetujuan DPR telah mengeluarkan kebijakan berupa UUPT. ${ }^{11}$ UUPT sesungguhnya merupakan pengganti dari UU BHP (Badan Hukum Pendidikan) yang dibatalkan oleh Mahkamah Konstitusi pada tahun 2010, dikarenakan lemah secara yuridis dan terlihat kuat komersialisasi pendidikannya. Mahkamah Konstitusi menyatakan bahwa UU BHP bertentangan dengan UUD 1945, karena mengalihkan tanggung jawab utama penyelenggaraan pendidikan dari negara, bangunan dan norma UU-nya keluar dari rambu-rambu konstitusi, tidak memberi ruang kemajemukan pendidikan, prinsip otonomi dan nirlaba tanpa jaminan pendidikan murah, serta membuka kemungkinan berkurangnya kekayaan negara/daerah tanpa persetujuan wakil rakyat.12

${ }^{9}$ Dikutip dari A. Syafii Maarif, Peta Bumi Intelektualisme Islam di Indonesia, cet. I, (Bandung: Mizan 1993), h. 135.

${ }^{10}$ A. Syafii Maarif, Peta Bumi Intelektualisme Islam di Indonesia, h. 140.

11Mengenai sejarah perjalanan UUPT ini, lihat misalnya Djoko Luknanto, "UU RI No. 12 Tahun 2012 tentang Pendidikan Tinggi”, http://luk.tsipil.ugm.ac.id/atur/UU12-2012/, diakses pada 25 Mei 2013.

12Mahkamah Konstitusi, Membangun Demokrasi Substantif, Meneguhkan Integritas Institusi: Laporan Tahunan 2010, cet. I, Jakarta: Sekretariat Jenderal dan Kepaniteraan Mahkamah Konstitusi, 2010), h. 51. 
Menurut Panja RUU Pendidikan Tinggi Komisi X DPR RI, proses perancangan UU PT oleh DPR dimulai sejak bulan April 2011, yaitu sebagai RUU inisiatif DPR. RUU tentang Pendidikan Tinggi ini kemudian dikirim kepada Pemerintah, untuk kemudian Pemerintah melalui Surat Presiden tanggal 28 April 2011 menugaskan para menteri terkait sebagai wakil Pemerintah untuk membahas RUU ini. Surat Presiden ini selanjutnya ditindaklanjuti oleh Badan Musyawarah (Bamus) DPR RI dengan menugaskan Komisi X DPR RI, untuk melakukan pembahasan RUU-PT bersama dengan Pemerintah. Dalam Rapat Internal Panja RUU Pendidikan Tinggi Komisi X DPR RI pada tanggal 13 Februari 2012, diputuskan untuk melaksanakan uji publik dalam rangka mencari masukan untuk penyempurnaan substansi RUU-PT tersebut, yang kemudian lahirlah Draf RUU Pendidikan Tinggi versi 22 Februari 2012.13

Sebelum Draf RUU-PT versi 22 Februari 2012 lahir, Panja RUU Pendidikan Tinggi Komisi X DPR RI sebenarnya telah memiliki draf tersendiri, yaitu Draf RUU-PT versi 4 Maret 2011 yang diajukan pada Rapat Paripurna tanggal 7 Maret 2011, dan Draf RUU-PT versi 14 Desember 2011 yang diajukan dalam Rapat Internal Panja RUU Pendidikan Tinggi Komisi X DPR RI tanggal 13 Februari 2012. Di dalam kedua draf Panja ini, belum ditemukan adanya "ilmu agama" sebagai salah satu rumpun ilmu pengetahuan dan teknologi. Ketika di dalam internal Panja terjadi perdebatan, Fraksi PPP mengusulkan agar agama dimasukkan sebagai salah satu rumpun agama. Dr. Reni Marlinawati yang merupakan Anggota Komisi X dari Fraksi PPP, dalam web resmi Fraksi PPP telah mengkritisi RUU-PT sebagai RUU yang berparadigma positivisme, yang menganggap agama sebagai bagian dari ranah budaya, masuk dalam rumpun humaniora. Menurutnya, agama harus dilihat dari aspek agama sebagai sebuah metode pencarian, yang dengan ini akan memberikan metodologi dalam melakukan pencarian itu. Oleh karena itu, "perbaikan terhadap RUU ini harus terus dilakukan agar tidak jauh panggang dari api, dengan kata lain, senafas dengan Preambul UUD 1945 dan sila pertama dari Pancasila."14

Sejak itu, draf RUU-PT ini diperbaiki, yang kemudian lahir Draf RUU-PT versi 22 Februari 2012.15 Khusus untuk Pasal 11 ayat (2) ini, Panja RUU-PT

\footnotetext{
13Panja RUU Pendidikan Tinggi Komisi X DPR RI, “Kerangka Acuan Kunjungan Kerja Panja Komisi XDPR RI dalam Rangka Masukan terhadap RUU tentang Pendidikan Tinggi ke Universitas Hasanuddin, Universitas Brawijaya dan Universitas Lambung Mangkurat", 2012, h. 3-4.

${ }^{14}$ Reni Marlinawati, "Jauh Panggang dari Api: Rancangan Undang-Undang Pendidikan Tinggi", http://fppp.or.id/web/berita/1020\#.UUSxNDqxlYw, diakses pada 24 Mei 2013.

15RUU Pendidikan Tinggi Hasil Panja RUU DIKTI 22 Februari 2012 untuk Bahan Uji Publik, pasal 11 ayat (2).
} 
Komisi X DPR RI melakukan uji publik ke Universitas Hasanuddin Provinsi Sulawesi Selatan, Universitas Brawijaya Provinsi Jawa Timur, dan Universitas Lambung Mangkurat Provinsi Kalimantan Selatan, dengan membawa sepuluh pokok permasalahan, yang di antaranya adalah: "Apakah substansi Rumpun Ilmu Pengetahuan (Pasal 11) perlu dicantumkan "Ilmu Agama”? Jika perlu/ tidak perlu, berikan penjelasan."16

Dari hasil dari uji publik itu, Panja menyusun Draf RUU-PT versi 4 April 2012. Di dalam Pasal 10 ayat (2) draf RUU ini disebutkan bahwa "Rumpun ilmu pengetahuan dan teknologi sebagaimana dimaksud pada ayat (1) terdiri atas: a. ilmu agama; b. ilmu humaniora; c. ilmu sosial; d. ilmu alam; e. ilmu formal; dan f. ilmu terapan. ${ }^{17}$ Draf RUU-PT inilah yang kemudian disahkan menjadi UU. Itulah proses politik yang akhirnya memasukkan "rumpun ilmu agama" sebagai salah satu rumpun ilmu pengetahuan dan teknologi, sebagaimana terlihat dalam Pasal 10 ayat (2) UUPT,18 yang menjadi mandat keilmuan bagi penyelenggaraan pendidikan oleh PTKI di Indonesia.

\section{Epistemologi Integrasi Keilmuan UIN}

Dikotomi yang cukup tajam antara keilmuan sekuler dan keilmuan agama telah membuat keduanya seolah mempunyai wilayah sendiri. Persoalan dikotomi inilah yang menjadi akar krusial epistemologi keilmuan di kalangan PTKI di Indonesia. Oleh karena itu, sejak tahun 2000-an kalangan cendekiawan PTKI sudah mulai mewacanakan mengenai upaya menghilangkan dikotomi keilmuan ini, utamanya dalam rangka pendirian UIN di seluruh Indonesia. Hingga 2015, terdapat 11 UIN di Indonesia, yaitu: UIN Syarif Hidayatullah, UIN Sunan Kalijaga, UIN Maulana Malik Ibrahim, UIN Sunan Gunung Djati, UIN Alauddin, UIN Sultan Syarif Kasim, UIN Sunan Ampel, UIN Walisongo, UIN Raden Fatah, UIN Ar-Raniry, dan UIN Sumatera Utara.

Akan tetapi, dari jumlah ini,terdapat tujuh epistemologi integrasi keilmuan yang sudah dirancangbangunkan di tujuh UIN, yaitu UIN Syarif Hidayatullah, UIN Sunan Kalijaga, UIN Maulana Malik Ibrahim, UIN Sunan Gunung Djati, UIN Alauddin, UIN Sunan Ampel, dan UIN Walisongo. Empat UIN di wilayah Sumatera, yaitu UIN Sultan Syarif Kasim, UIN Raden Fatah, UIN Ar-Raniry, dan

\footnotetext{
16Panja RUU Pendidikan Tinggi Komisi X DPR RI, “Kerangka Acuan”, h. 4-5.

17RUU Pendidikan Tinggi Hasil Panja 04 April 2012, pasal 10 ayat (2).

18UU No. 12 Tahun 2012 tentang Pendidikan Tinggi, pasal 10 ayat (2).
} 
UIN Sumatera Utara, berdasarkan survei literatur, belum memiliki konsep integrasi keilmuan yang jelas, yang karenanya tidak masuk dalam kajian ini. Berikut gambaran epistemologi integrasi keilmuan ketujuh UIN tersebut.

\section{UIN Syarif Hidayatullah Jakarta: Reintegrasi Keilmuan}

Menurut Azyumardi Azra, konsep dasar awal pengembangan IAIN Jakarta pada 1990-an adalah perubahan IAIN Jakarta menjadi UIN "Syarif Hidayatullah" Jakarta, atau Universitas Islam Syarif Hidayatullah. Gagasan menjadi UIN ini bertitik tolak dari beberapa masalah yang dihadapi IAIN selama ini, yaitu: pertama, IAIN belum berperan secara optimal dalam dunia akademik, birokrasi dan masyarakat Indonesia secara keseluruhan. Di antara ketiga lingkungan ini, kelihatannya peran IAIN lebih besar pada masyarakat, karena kuatnya orientasi dakwah daripada pengembangan ilmu pengetahuan. Kedua, kurikulum IAIN belum mampu meresponsi perkembangan IPTEK dan perubahan masyarakat yang semakin kompleks. Hal ini disebabkan bidang kajian agama yang merupakan spesialiasi IAIN, kurang mengalami interaksi dan reapproachement dengan ilmu-ilmu umum, bahkan masih cenderung dikotomis.19

Langkah perubahan bentuk IAIN menjadi UIN mendapat rekomendasi Pemerintah dengan ditandatanganinya Surat Keputusan Bersama (SKB) antara Menteri Pendidikan Nasional RI dan Menteri Agama RI tanggal 21 November 2001, yang kemudian ditindaklanjuti dengan keluarnya Keputusan Presiden No. 031 Tanggal 20 Mei Tahun 2002 tentang Perubahan IAIN Syarif Hidayatullah Jakarta menjadi UIN Syarif Hidayatullah Jakarta. Menanggapi ditandatanganinya SKB ini, Prof. Azra menilai bahwa "Penandatanganan ini tentu saja menandai sejarah baru IAIN Jakarta. Kita bertekad untuk tidak mengadakan dikotomi antara ilmu agama dan ilmu non-agama" ${ }^{20}$ Konsep reintegrasi keilmuan di atas untuk kali pertama digagas oleh Azyumardi Azra. Menurutnya, diperlukan rekonsiliasi dan reintegrasi antar ilmu-ilmu agama dengan ilmu-ilmu umum, yaitu kembali pada kesatuan transenden semua ilmu pengetahuan..$^{21}$ Oleh karena

\footnotetext{
${ }^{19}$ Azyumardi Azra, "IAIN di Tengah Paradigma Baru Perguruan Tinggi" dalam Komaruddin Hidayat dan Hendro Prasetyo, Problem dan Prospek IAIN: Antologi Pendidikan Tinggi Islam, (Jakarta: Dirjen Binbaga Islam, 2000), h. 13.

${ }^{20}$ Dikutip dari Oman Fathurrahman, "Prof. Dr. Azyumardi Azra, M.A.: Mewujudkan 'Mimpi' IAIN menjadi UIN" dalam Badri Yatim dan Hamid Nasuhi (ed.), Membangun Pusat Keunggulan Studi Islam, (Jakarta: IAIN Jakarta Press, 2002), h. 323.

${ }^{21}$ Azyumardi Azra, "Reintegrasi Ilmu-ilmu dalam Islam" dalam Zainal Abidin Bagir, dkk. (eds.), Integrasi Ilmu dan Agama: Interpretasi dan Aksi, cet. I, (Bandung: Mizan, 2005), h. 210-211.
} 
itu, UIN Syarif Hidayatullah Jakarta mengarahkan dirinya pada integrasi keilmuan model ini, berdasarkan pada keyakinan, pengetahuan dan amal saleh, yang untuk kemudian menjadi basis universitas bagi pengembangan keilmuannya.

\section{UIN Sunan Kalijaga Yogyakarta: Integrasi “Jaring Laba-laba”}

Salah satu perkembangan signifikan yang cukup penting bagi kelembagaan pendidikan tinggi Islam di Indonesia adalah transformasi IAIN Sunan Kalijaga menjadi UIN Sunan Kalijaga berdasarkan Keputusan Presiden No. 50 Tahun 2004 Tanggal 21 Juni 2004. Perubahan institut menjadi universitas dilakukan untuk mencanangkan sebuah paradigma baru dalam melihat dan melakukan studi terhadap ilmu-ilmu agama dan ilmu-ilmu umum, yaitu paradigma integrasi-interkoneksi. Pemaduan (integrasi) dan pengaitan (interkoneksi) kedua bidang ilmu yang sebelumnya dipandang secara diametral berbeda itu, memungkinkan lahirnya pemahaman Islam yang ramah, demokratis, dan menjadi raḥmah li 'l-'âlamìn. ${ }^{22}$

Dengan visi "Unggul dan terkemuka dalam pemaduan dan pengembangan studi keislaman dan keilmuan bagi peradaban", UIN Sunan Kalijaga memiliki core values, yang salah satunya adalah epistemologi keilmuan "integrasiinterkoneksi", yaitu adanya sistem keterpaduan dalam pengembangan akademik, manajemen, kemahasiswaan, kerjasama, dan entrepreneurship. ${ }^{23}$ Epistemologi ini merupakan gagasan Prof. M. Amin Abdullah ketika menjadi Rektor UIN Sunan Kalijaga. Menurut Amin Abdullah, jika selama ini terdapat sekatsekat yang sangat tajam antara "ilmu" dan "agama" di mana keduanya seolah menjadi entitas yang berdiri sendiri, mempunyai wilayah sendiri baik dari segi objek-formal-material, metode penelitian, kriteria kebenaran, peran yang dimainkan oleh ilmuwan hingga institusi penyelenggaranya, maka tawaran paradigma integrasi-interkoneksi berupaya mengurangi ketegangan-ketegangan tersebut dengan berusaha mendekatkan dan mengaitkannya sehingga menjadi "bertegur sapa" satu sama lain. ${ }^{24}$

\footnotetext{
${ }^{22}$ Silakan akses Tim Redaksi, "Sekilas UIN Sunan Kalijaga”, http://www.uinsuka.ac.id/id/about/ universitas-1-sekilas-uin.html, diakses pada 12 Juni 2011.

${ }^{23}$ Tim Redaksi, "Core Values”, http://uin-suka.ac.id/index.php/page/universitas/29-corevalues, diakses pada 12 Desember 2013.

${ }^{24} \mathrm{M}$. Amin Abdullah, Islamic Studies di Perguruan Tinggi: Paradigma Integratif-Interkonektif, Cet. I, (Yogyakarta: Pustaka Pelajar, 2006), h. 92-93.
} 
Dalam epistemologi keilmuan integrasi-interkoneksi itu, tiga wilayah pokok ilmu pengetahuan, yakni natural sciences, social sciences dan humanities tidak lagi berdiri sendiri, tetapi akan saling terkait satu dengan lainnya. ${ }^{25}$ Antara Haḍārah al-'Ilm yaitu ilmu-ilmu empiris yang masuk kategori sains dan teknologi, Haḍārah al-Falsafah yaitu ilmu-ilmu rasional seperti filsafat dan budaya, dan Haḍārah al-Nas yaitu ilmu-ilmu normatif tekstual seperti fiqh, kalam, tasawuf, tafsir, hadits, falsafah, dan lughah, akan terintegrasi dan terkoneksi dalam satu keilmuan integrasi. ${ }^{26}$ Dengan model integrasi ini, maka tiga wilayah keilmuan Islam menjadi terintegrasi-terkoneksi. Tiga dimensi pengembangan wilayah keilmuan ini bertujuan untuk mempertemukan kembali ilmu-ilmu modern dengan ilmu-ilmu keislaman secara integratifinterkonektif, yang tampak dalam "Jaring Laba-Laba" sebagai berikut:27

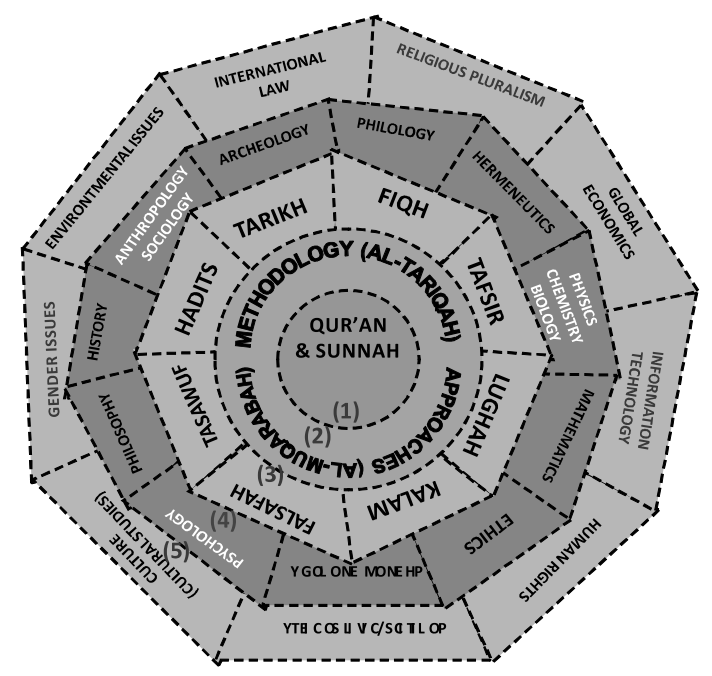

Epistemologi integrasi "Jaring Laba-laba" di atas menunjukkan bahwa aktivitas keilmuan di PTKI di seluruh tanah air hanya terfokus dan terbatas pada jalur Lingkar Lapis Satu dan jalur Lingkar Lapis Dua, yang terdiri atas

${ }^{25}$ M. Amin Abdullah, Islamic Studies di Perguruan Tinggi ..., h. 370.

${ }^{26}$ M. Amin Abdullah, Islamic Studies di Perguruan Tinggi ..., h. 402-405.

${ }^{27}$ M. Amin Abdullah, Islamic Studies di Perguruan Tinggi ..., h. 107-108. 
Kalam, Falsafah, Tasawuf, Hadits, Tarikh, Fiqh, Tafsir, dan Lughah. Itupun boleh disebut hanya terbatas pada ruang gerak humaniora klasik. IAIN pada umumnya belum mampu memasuki diskusi ilmu-ilmu sosial dan humanities kontemporer seperti tergambar pada jalur Lingkar Tiga (Antropologi, Sosiologi, Psikologi, Filsafat dengan berbagai pendekatan yang ditawarkannya). Akibatnya, terjadi jurang wawasan keislaman yang tidak terjembatani antara ilmuilmu keislaman klasik dan ilmu-ilmu keislaman baru yang telah memanfaatkan analisis ilmu-ilmu sosial dan humaniora kontemporer. ${ }^{28}$

\section{UIN Maulana Malik Ibrahim Malang: Integrasi "Pohon Ilmu"}

Usulan STAIN Malang menjadi universitas disetujui Presiden melalui Surat Keputusan Presiden RI No. 50 Tanggal 21 Juni 2004. Menurut SK Presiden ini, tugas utama UIN Malang adalah menyelenggarakan program pendidikan tinggi bidang ilmu agama Islam dan bidang ilmu umum. Secara akademik, UIN Malang mengembangkan ilmu pengetahuan tidak saja bersumber dari metode-metode ilmiah melalui penalaran logis seperti observasi dan eksperimentasi, tetapi juga bersumber dari al-Qur'an dan Hadits, yang selanjutnya disebut paradigma integrasi. Dalam paradigma ini, posisi al-Qur'an dan Hadits menjadi sangat sentral dalam kerangka integrasi keilmuan tersebut.

Adalah Prof. Imam Suprayogo yang mencoba membangun konsep integrasi keilmuan bagi UIN Malang. Menurut Suprayogo, kehadiran UIN dengan konsep integrasi dimaksudkan untuk menghilangkan dikotomi ilmu pengetahuan. Islam adalah agama, sekaligus ilmu dan peradaban yang tinggi. Bahkan, kemunduruan umat Islam di antaranya adalah sebagai akibat adanya dikotomi ilmu pengetahuan ini. Oleh karena itu, salah satu upaya fundamental dan strategis yang ditempuh UIN Malang adalah melakukan rekonstruksi paradigma keilmuan, dengan meletakkan agama sebagai basis ilmu pengetahuan. Setelah melalui perenungan yang mendalam, akhirnya Imam Suprayogo menemukan format integrasi keilmuan bagi UIN Malang dengan metafora "Pohon Ilmu" sebagai berikut:29

\footnotetext{
28M. Amin Abdullah, Islamic Studies di Perguruan Tinggi ..., h. 109.

${ }^{29}$ Imam Suprayogo, Paradigma Pengembangan Keilmuan Islam Perspektif UIN Malang, (Malang: UIN-Malang Press, 2006), h. 57.
} 


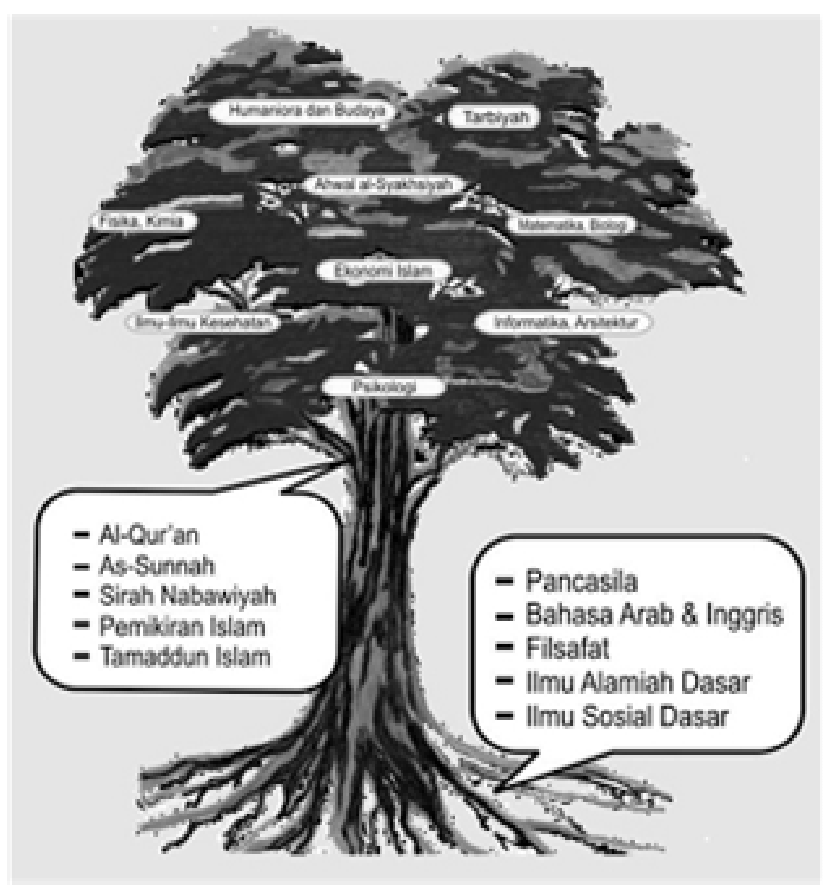

Dari gambar pohon di atas diketahui bahwa bangunan struktur keilmuan UIN Malang didasarkan pada universalitas ajaran Islam. Metafora yang digunakan adalah sebuah pohon yang kokoh, bercabang rindang, berdaun subur, dan berbuah lebat karena ditopang oleh akar yang kuat. Akar pohon menggambarkan landasan keilmuan universitas, yaitu Bahasa Arab dan Inggris, Filsafat, Ilmu-ilmu Alam, Ilmu-ilmu Sosial, dan Pendidikan Pancasila dan Kewarganegaraan. Penguasaan landasan keilmuan ini menjadi modal dasar bagi mahasiswa untuk memahami keseluruhan aspek keilmuan Islam, yang digambarkan sebagai pokok pohon yang menjadi jati-diri mahasiswa universitas ini, yaitu: al-Qur'an dan al-Sunnah, Sirah Nabawiyah, Pemikiran Islam, dan Wawasan Kemasyarakatan Islam. Dahan dan ranting mewakili bidang-bidang keilmuan universitas ini yang senantiasa tumbuh dan berkembang. Bunga dan buah menggambarkan keluaran dan manfaat upaya pendidikan universitas ini, yaitu: keberimanan, kesalehan, dan keberilmuan. ${ }^{30}$

\footnotetext{
30Silakan akses "Struktur Keilmuan" dalam http://www.uinmalang.ac.id/index.php?option= com_content\&view=article\&id=7:struktur-keilmuan\&catid=1:pendahuluan\&Itemid=144, diakses pada 10 Desember 2013.
} 


\section{UIN Sunan Gunung Djati Bandung: Integrasi “Roda Ilmu”}

Berdasarkan Keputusan Presiden Republik Indonesia Nomor 57/2005 tanggal 10 Oktober 2005, status IAIN Bandung diubah menjadi UIN Sunan Gunung Djati Bandung. Adalah Prof. Nanat Fatah Natsir yang telah menggagas model integrasi bagi keilmuan UIN Bandung dengan metafora "Roda Ilmu" sebagai berikut: ${ }^{31}$

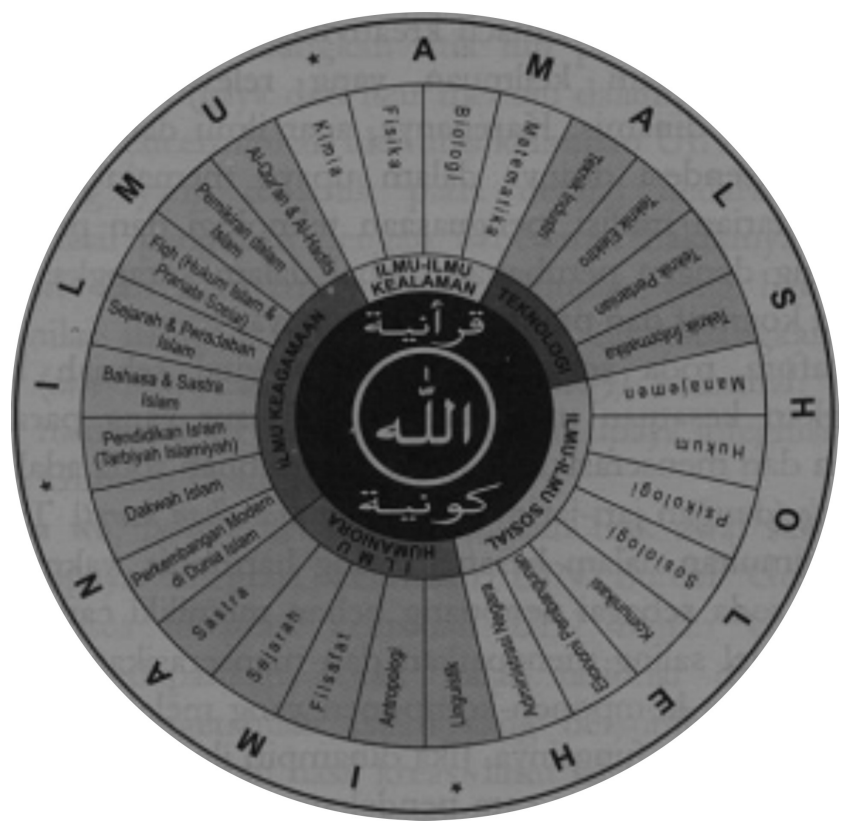

Menurut Fatah Natsir, roda adalah bagian yang esensial dari sebuah kendaraan yang bergerak dinamis. Secara fisik, sebuah roda itu memiliki tiga bagian, yaitu bagian as (poros), bagian velg (dengan jari-jarinya) dan bagian ban luar (ban karet), yang dapat bekerja secara simultan dalam kesatuan yang harmonis. Ibarat sebuah roda dengan tiga bagiannya, maka keilmuan UIN Bandung mengacu pada "Filosofi Roda" sebagai berikut:

${ }^{31}$ Nanat Fatah Natsir, "Merumuskan Landasan Epistemologi Pengintegrasian Ilmu Qur'aniyyah dan Kawniyyah" dalam Tim Editor (eds.), Pandangan Keilmuan UIN: Wahyu Memandu Ilmu, cet. I, (Bandung: Gunung Djati Press, 2006), h. 32. 
a. As atau poros roda melambangkan titik sentral kekuatan akal budi manusia yang bersumber dan nilai-nilai ilahiyah, yaitu Allah sebagai sumber dari segala sumber. Titik sentral ini mencerminkan pusat pancaran nilai-nilai keutamaan yang berasal dari pemilik-Nya, sekaligus titik tujuan seluruh ikhtiar manusia. Dengan kata lain, tawhìd merupakan pondasi pengembangan seluruh ilmu, baik yang bersumber dari ayat-ayat qur'āniyyah ataupun dari ayat-ayat kawniyyah.

b. Velg roda yang terdiri atas sejumlah jari-jari, lingkaran bagian dalam, dan lingkaran luar, melambangkan rumpun ilmu dengan beragam jenis disiplin yang berkembang saat ini. Meskipun setiap ilmu memiliki karakteristiknya masing-masing, tetapi memiliki fungsi yang sama, yakni ilmu sebagai alat untuk memahami hakikat hidup. Adanya aneka warna disiplin ilmu sejatinya tidak menunjukan keterpisahan yang dapat dimanfaatkan manusia sebagai fasilitas hidupnya. Putaran velg pada roda melambangkan bahwa setiap ilmu yang dikembangkan di UIN Sunan Gunung Djati Bandung selalu memperluas cakrawala cakupannya, untuk secara terus-menerus berkembang sesuai perkembangan zaman.

c. Ban luar yang terbuat dari karet melambangkan realitas kehidupan yang tidak terpisahkan dari semangat nilai-nilai ilahiyah dan gairah kajian ilmu. Pada sisi luar ban, terlambang tiga istilah, yaitu iman, ilmu dan amal saleh. Inilah target akhir dari profil lulusan UIN. Kekuatan iman ditanamkan melalui proses pendidikan dalam situasi kampus yang ilmiah dan religius. Kekuatan ilmu merupakan basis yang dimiliki UIN Sunan Gunung Djati Bandung yang mencerminkan dinamika kampus sebagai zona pergumulan para ilmuwan. Sedangkan amal saleh sebagai wujud perilaku yang terbimbing oleh iman dan ilmu. ${ }^{32}$

\section{UIN Alauddin Makassar: Integrasi “Sel Cemara Ilmu”}

Untuk merespons tuntutan perkembangan ilmu pengetahuan dan teknologi, diusulkanlah konversi IAIN Alauddin Makassar menjadi UIN Alauddin Makassar. Berdasarkan Peraturan Presiden Republik Indonesia No. 57 Tahun

\footnotetext{
${ }^{32}$ Nanat Fatah Natsir, "Merumuskan Landasan Epistemologi Pengintegrasian Ilmu Qur'aniyyah dan Kawniyyah" dalam Tim Editor (eds.), Pandangan Keilmuan UIN: Wahyu Memandu Ilmu, cet. I, (Bandung: Gunung Djati Press, 2006), h. 32-43.
} 
2005 Tanggal 10 Oktober 2005, IAIN Alauddin Makassar telah resmi alih status menjadi UIN Alauddin Makassar.

Konsep integrasi keilmuan UIN Makassar digagas oleh Prof. Azhar Arsyad dengan metafora "Sel Cemara Ilmu" yang mengintegrasikan dan mengkoneksikan antara sains dan ilmu agama. Menurutnya, "Sel Cemara Ilmu" mengandung metaforis akar, alur, ranting dan buah dan tujuan transendental ilmu pengetahuan yang sifatnya universal, yang bisa terwujuddalam suatu wadah yang namanya universitas. ${ }^{33}$ Ilustrasi metaforis "Sel Cemara Ilmu" dapat dilihat dalam gambar berikut:

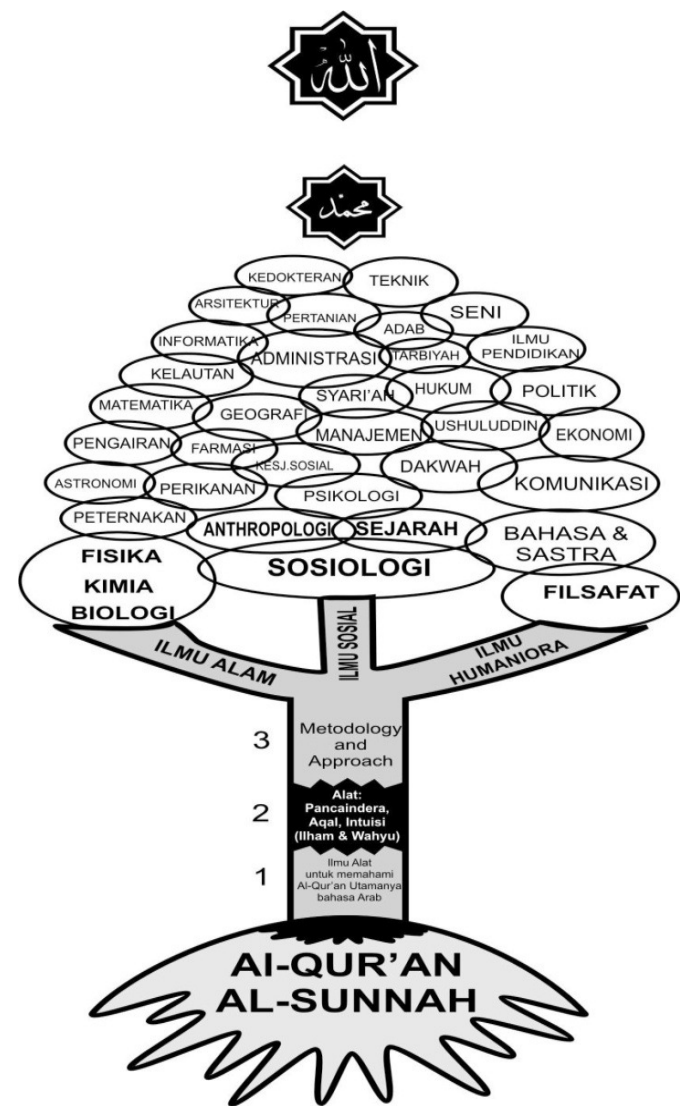

${ }^{33}$ Azhar Arsyad, "Buah Cemara Integrasi dan Interkoneksitas Sains dan Ilmu Agama", Hunafa: Jurnal Studia Islamika, Vol. 8, No.1, Juni 2011, h.11-12. 
Gambaran pohon cemara itu mengindikasikan sesuatu yang hidup, tidak mati, sejuk dipandang. Karena ia pohon, maka ia makin lama makin tumbuh, dan berkembang, lalu mengerucut. Makin lama makin rindang. Pohon ini akan menghasilkan buah, dan buah itulah yang menjadi nama suatu ilmu, yang tentunya akan berbuah lagi. Bagian-bagiannya terintegrasi dan berinterkoneksi. Gambaran sel menggambarkan segi-segi interkoneksitas sintetik, sementara cemara menggambarkan transendental akhir, melalui kerasulan Muhammad menuju Allah.

\section{UIN Sunan Ampel Surabaya: Integrasi “Menara Kembar Tersambung"}

Berdasarkan Peraturan Presiden No. 65 Tahun 2013, IAIN Sunan Ampel secara resmi diakui perubahan bentuk kelembagaannya dari institut menjadi univeritas, yaitu UIN Sunan Ampel Surabaya. Perubahan status kelembagaan ini menuntut UIN Sunan Ampel untuk merancang konsep integrasi keilmuannya. Untuk menjalankan visinya, yaitu "Menjadi Universitas Islam yang unggul dan kompetitif bertaraf internasional", 34 UIN Sunan Ampel mengembangkan paradigma integrasi keilmuan yang disebut "Menara Kembar Tersambung" atau Integrated Twin Towers. ${ }^{35}$ Paradigma integrasi keilmuan ini pada mulanya bernama Twin Towers (Menara Kembar) yang untuk kali pertama digagas oleh Prof. Nur Syam pada saat ia menjabat sebagai rektor. Menurutnya, konsep "Menara Kembar" (Twin Towers) diusungnya pada saat ia mencalonkan diri sebagai rektor pada Agustus 2008, sebagai tawaran untuk memberi label bagi ilmu keislaman yang khas bagi IAIN Sunan Ampel Surabaya. ${ }^{36}$

Sejak 2013, paradigma Twin Towers (Menara Kembar) berubah menjadi "Menara Kembar Tersambung" atau Integrated Twin Towers. Menurut Tim UIN Sunan Ampel Surabaya dalam buku Desain Akademik UIN Sunan Ampel Surabaya: Buiding Character Qualities for the Smart, Pious and Honourable Nation, secara epistemologis, paradigma keilmuan "Integrated Twin Towers"

\footnotetext{
${ }^{34}$ Silakan akses Tim Redaksi, "Visi, Misi dan Tagline”, http://www.uinsby.ac.id/id/185/visi-misidan-tagline.html, diakses pada 20 November 2015.

${ }^{35}$ Silakan akses Tim Redaksi, "Paradigma Keilmuan", http://www.uinsby.ac.id/id/251/ paradigma-keilmuan.html, diakses pada 20 November 2015.

${ }^{36}$ Nur Syam, "Model Twin Towers untuk Islamic Studies", http://nursyam.uinsby.ac.id/?p=762, diakses pada 20 November 2015.
} 
berusaha membangun struktur keilmuan yang memungkinkan ilmu keagamaan dan ilmu sosial/humaniora serta ilmu alam berkembang secara memadai dan wajar. Keduanya memiliki kewibawaan yang sama, sehingga antara satu dengan lainnya tidak saling merasa superior atau inferior. Ilmu keislaman berkembang dalam kapasitas dan kemungkinan perkembangannya, demikian pula ilmu lainnya juga berkembang dalam rentangan dan kapasitasnya. Ilmu keislaman laksana sebuah menara yang satu, dan ilmu lainnya seperti menara satunya lagi. Keduanya tersambung dan bertemu dalam puncak yang saling menyapa, yang dikenal dengan konsep ilmu keislaman multidisipliner. Menara yang satu menjadi subject matter dan lainnya sebagai pendekatan. ${ }^{37}$

Berikut dikemukakan gambar yang mengilustrasikan paradigma integrasi keilmuan "Menara Kembar Tersambung" UIN Sunan Ampel. ${ }^{38}$ Pada gambar berikut menjelaskan bahwa paradigma integrasi keilmuan "Menara Kembar Tersambung" UIN Sunan Ampel bermaksud melahirkan lulusan yang ulu al$a l b a ̄ b$ sebagai sumber daya manusia yang mampu mengintegrasikan antara praktik zikir dan pikir dalam praktik kehidupan sehari-hari. ${ }^{39}$ Dia juga memiliki kedewasaan bersikap dan mampu mengambil pilihan yang terbaik dalam hidup berdasarkan petunjuk ilahi, ${ }^{40}$ di samping mampu mempersembahkan kemapanan intelektual. ${ }^{41}$ Secara konkret, lulusan yang ulu al-albāb diterjemahkan dalam Standar Kompetensi Lulusan (SKL) yang memiliki kekayaan intelektual, kematangan spiritual, dan kearifan perilaku.

Kekayaan intelektual diharapkan mampu mengatarkan individu lulusan yang memiliki kepribadian smart (cerdas). Kematangan spiritual diidealisasikan agar tertanam kuat dalam diri individu lulusan kepribadian honourable (bermartabat). Kearifan perilaku dimaksudkan agar individu lulusan diperkaya dengan kepribadian pious (berbudi luhur).42

\footnotetext{
37Tim UIN Sunan Ampel Surabaya, Desain Akademik UIN Sunan Ampel Surabaya: Buiding Character Qualities for the Smart, Pious and Honourable Nation, cet. II, (Surabaya: UINSA Press, 2015), h. 34-35.

38Tim UIN Sunan Ampel Surabaya, Desain Akademik UIN Sunan Ampel Surabaya..., ), h. 47.

${ }^{39}$ QS.. al-Zumar [39]: 9; QS. Ali Imran [3]: 7.

${ }^{40}$ QS. al-Zumar [39]: 18; QS. al-Ma'idah [5]:100.

${ }^{41}$ QS. al-Zumar [39]: 18; QS. Ali Imran [3]: 190.

42Tim UIN Sunan Ampel Surabaya, Desain Akademik UIN Sunan Ampel Surabaya ..., h. 46.
} 


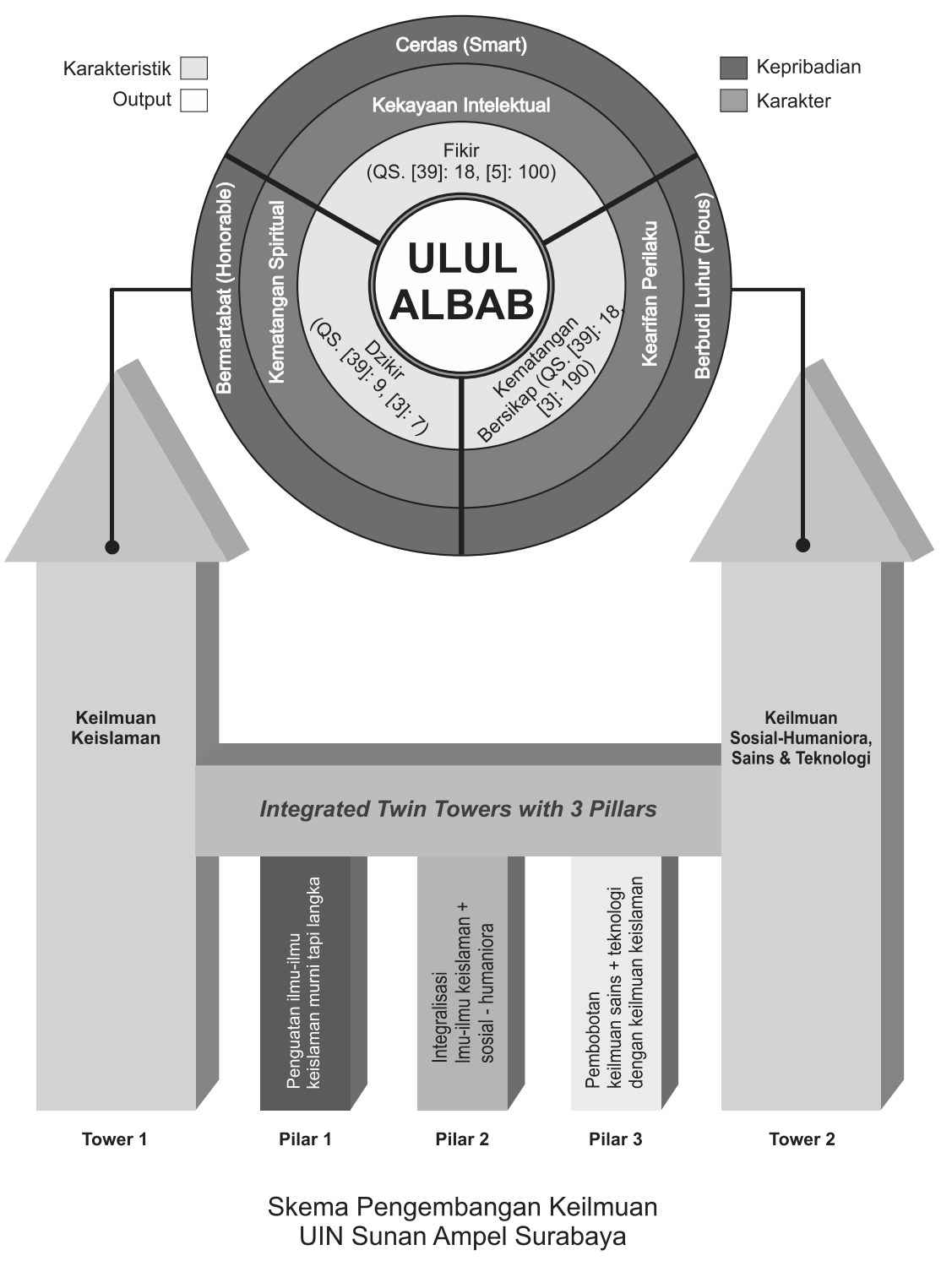

Untuk melahirkan lulusan seperti ini, UIN Sunan Ampel merancang integrasi keilmuan yang "menyambungkan" antara Menara I (Keilmuan Keislaman) dengan Menara II (Keilmuan Humaniora, Sains dan Teknologi). Ketersambungan kedua menara ini diantarai oleh tiga pilar, yaitu pilar: a) penguatan 
ilmu-ilmu keislaman murni tapi langka, b) integrasi ilmu-ilmu keislaman dan sosial-humaniora, dan c) pembobotan keilmuan sains dan teknologi dengan keilmuan keislaman.

\section{UIN Walisongo Semarang: Integrasi “Intan Berlian Ilmu”}

IAIN Walisongo Semarang resmi menjadi Universitas Islam Negeri (UIN) Walisongo sejak 19 Desember 2014, yang peresmiannya bersamaan dengan dua UIN yang lain, yaitu UIN Raden Fatah Palembang dan UIN Sumatera Utara. Untuk mengembangkan paradigma integrasi keilmuannya, UIN Walisongo merancang integrasi "Kesatuan Ilmu" (Unity of Sciences/Waḥdat al-'Ulüm) dengan model "Intan Berlian Ilmu", yang digagas oleh Dr. H. Abdul Muhaya, M.A. dan Dr. H. Muhyar Fanani, M.Ag. ${ }^{43}$ Menurut Muhyar Fanani, yang dimaksud dengan paradigma ini adalah bahwa semua ilmu pada dasarnya adalah satu kesatuan yang berasal dari dan bermuara pada Allah melalui wahyu-Nya, baik secara langsung ataupun tidak langsung. Oleh karena itu, semua ilmu mestinya berdialog dan bermuara pada satu tujuan, yaitu mengantarkan pengkajinya untuk semakin mengenal dan dekat dengan Allah sebagai al-'̄́lim (yang Mahatahu). ${ }^{44}$

Di tengah hiruk-pikuk semangat dan tanggug jawab keilmuan perguruan tinggi, paradigma "Kesatuan Ilmu" ini telah ditegaskan sebagai paradigma keilmuan institusi IAIN Walisongo. Dalam paradigma ini, wahyu dipandang sebagai fondasi perekat bagi penyatuan ilmu pengetahuan. Ilmu selalu berproses dan berdialog menuju tujuan tunggal, yaitu Sang Pencipta yang Mahatahu. Lulusan yang dihasilkan dari paradigma integrasi "Kesatuan Ilmu" ini adalah sosok pribadi yang komprehensif, yang mampu mengomunikasikan berbagai bidang ilmu dengan realitas. Paradigma integrasi "Kesatuan Ilmu” UIN Walisongo ini dapat digambarkan dengan model "Intan Berlian" yang cemerlang, berkilau dengan sinar indah, tajam, dan mencerahkan dengan lima sisi yang saling berkaitan. ${ }^{45}$

\footnotetext{
${ }^{43}$ Silakan akses Luthfiyatul Hiqmah, "Wahdatul Ulum sebagai Konsep Integrasi Islam dan Sains di UIN Walisongo", http://hiqmah12.blogspot.co.id/2014/05/wahdatul-ulum-sebagai-konsep-integrasi. html, diakses pada 20 November 2015.

${ }^{44}$ Muhyar Fanani, "Paradigma Kesatuan Ilmu (Unity of Sciences) dalam Visi dan Misi IAIN Walisongo", Presentasi dalam bentuk Powerpoint disampaikan pada 30 Oktober 2013 di Hotel Novotel, Semarang.

45Imam Taufiq, “Komitmen Kebangsaan IAIN”, Suara Merdeka, 7 April 2014.
} 
Berikut ditampilkan paradigma integrasi "Kesatuan Ilmu" UIN Walisongo dengan ilustrasi “Intan Berlian Ilmu” dari Muhyar Fanani:46

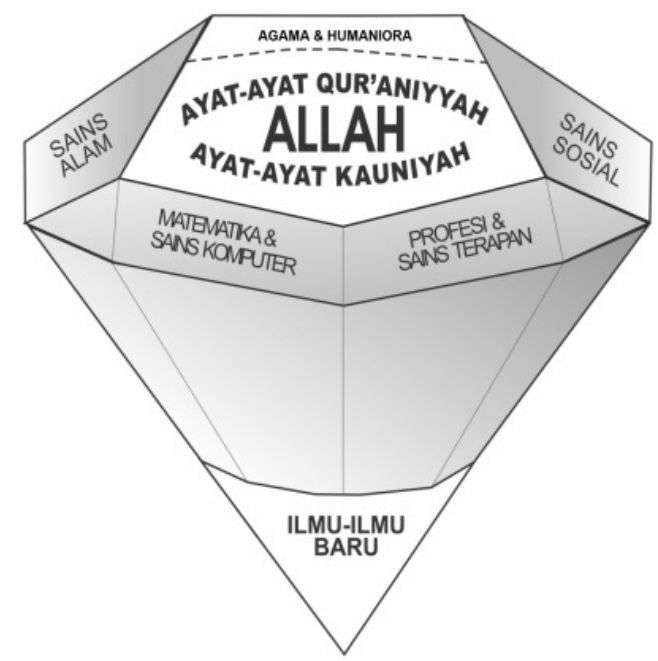

Di dalam mengilustrasikan paradigma integrasi "Kesatuan Ilmu" UIN Walisongo dengan metapora "intan berlian", Tsuwaibah memandang bahwa bahwa intan berlian itu sangat indah, bernilai tinggi, memancarkan sinar, memiliki sumbu dan sisi yang saling berhubungan satu sama lain. Sumbu paling tengah menggambarkan Allah sebagai sumber nilai, doktrin, dan ilmu pengetahuan. Allah menurunkan ayat-ayat Qur'aniyah dan ayat-ayat kawniyyah sebagai lahan eksplorasi pengetahuan yang saling melengkapi dan tidak mungkin saling bertentangan. Eksplorasi atas ayat-ayat Allah menghasilkan lima gugus ilmu, yaitu: a) Ilmu Agama dan Humaniora (religion and humanity sciences); b) Ilmu-ilmu Sosial (social sciences); c) Ilmu-ilmu Kealaman (natural sciences); d) Ilmu Matematika dan Sains Komputer (mathematics and computing sciences); dan e) Ilmu-ilmu Profesi dan Terapan (professions and applied sciences) ${ }^{47}$

\footnotetext{
46Muhyar Fanani, "Paradigma Kesatuan Ilmu (Unity of Sciences) dalam Visi dan Misi IAIN Walisongo", Presentasi dalam bentuk Powerpoint disampaikan pada 30 Oktober 2013 di Hotel Novotel, Semarang.

47Tsuwaibah, "Epistemologi Unity of Science Ibn Sina: Kajian Integrasi Keilmuan Ibn Sina dalam Kitab Asy-Syifa Juz I dan Relevansinya dengan Unity of Science IAIN Walisongo", Laporan Hasil Penelitian Individual, IAIN Walisongo Semarang, 2014, h. 72-73.
} 
Dari tujuh epistemologi integrasi keilmuan UIN di atas tampak bahwa keilmuan UIN telah menjadikan wahyu (al-Qur'an dan Sunnah) sebagai core atau basis bagi keilmuan yang dikembangkannya. Keilmuan model inilah yang dikembangkan kaum Muslim periode Klasik. Pada periode ini, apapun keahlian seorang intelektual Muslim, baik dalam bidang ilmu-ilmu alam, ilmu-ilmu sosial ataupun humaniora, senantiasa menjadikan sumber ajaran Islam (al-Qur'an dan Sunnah) sebagai basis dan core bagi spirit keilmuannya. Spirit ini pada gilirannya membawa intelektualisme Muslim mencapai era keemasannya, yang semuanya berkat semangat dan dorongan wahyu pertama, yang telah menjiwai kehidupan masyarakat Muslim pada saat itu. ${ }^{48}$

\section{Teo-Antropo-Kosmosentrisme: Reposisi Ilmu-ilmu Non-Rumpun Ilmu Agama}

Untuk tahun akademik 2015-2016, ketujuh UIN yang dikaji siap menerima mahasiswa baru. Berdasarkan situs Penerimaan Mahasiswa Baru (PMB) dari ketujuh UIN ini, diperoleh informasi mengenai fakultas dan program studi nonrumpun ilmu agama yang ditawarkannya sebagai berikut:

1. UIN Syarif Hidayatullah Jakarta membuka lima fakultas, yaitu: Fakultas Psikologi dengan Jurusan Psikologi; Fakultas Ekonomi dan Bisnis dengan lima jurusan (Manajemen, Akuntansi, Ilmu Ekonomi dan Studi Pembangunan, Perbankan Syariah, dan Ekonomi Syariah); Fakultas Sains dan Teknologi dengan tujuh jurusan (Agribisnis, Sistem Informasi, Teknik Informatika, Matematika, Biologi, Fisika dan Kimia); Fakultas Kedokteran dan Ilmu Kesehatan dengan empat jurusan (Kesehatan Masyarakat, Farmasi, Pendidikan Dokter, dan Ilmu Keperawatan); serta Fakultas Ilmu Sosial dan Ilmu Politik dengan tiga jurusan (Sosiologi, Ilmu Politik, dan Ilmu Hubungan Internasional). ${ }^{49}$

2. UIN Sunan Kalijaga Yogyakarta membuka dua fakultas, yaitu Fakultas Sains dan Teknologi dengan 10 jurusan (Matematika, Fisika, Kimia, Biologi, Teknik Informatika, Teknik Industri, Pendidikan Matematika, Pendidikan Biologi, 4.

${ }^{48}$ Abdullah Idi dan Toto Suharto, Revitalisasi Pendidikan Islam, (Yogyakarta: Tiara Wacana, 2006), h.

${ }^{49}$ Silakan akses Tim Redaksi, "Program Sarjana”, http://uinjkt.ac.id/id/akademik/programsarjana/, diakses pada 13 Agustus 2015. 
Pendidikan Fisika, dan Pendidikan Kimia); serta Fakultas Ilmu Sosial dan Humaniora dengan tiga jurusan (Psikologi, Sosiologi dan Ilmu Komunikasi).50

3. UIN Maulana Malik Ibrahim Malang membuka tiga fakultas, yaitu Fakultas Humaniora dengan tiga jurusan (Bahasa dan Sastra Arab, Bahasa dan Sastra Inggris, dan Pendidikan Bahasa Arab); Fakultas Psikologi dengan Jurusan Psikologi; Fakultas Ekonomi dengan tiga jurusan (Manajemen, Akuntansi dan Perbankan Syariah); serta Fakultas Sains dan Teknologi dengan tujuh jurusan (Matematika, Biologi, Kimia, Fisika, Teknik Informatika, Teknik Arsitektur, dan Farmasi). ${ }^{51}$

4. UIN Sunan Gunung Djati Bandung membuka tiga fakultas, yaitu Fakultas Psikologi dengan Jursan Psikologi; Fakultas Sains dan Teknologi dengan tujuh jurusan (Matematika, Biologi, Fisika, Kimia, Teknik Informatika, Pertanian/Agroteknologi, dan Teknik Elektro); serta Fakultas Ilmu Sosial dan Ilmu Politik dengan tiga jurusan (Sosiologi, Administrasi Negara dan Manajemen). ${ }^{52}$

5. UIN Alauddin Makassar membuka dua fakultas, yaitu Fakultas Sains dan Teknologi dengan sembilan jurusan (Teknik Informatia, Teknik Arsitektur, Teknik Perencanaan Wilayah dan Kota, Matematika, Biologi, Kimia, Fisika, Ilmu Peternakan dan Sistem Informasi); serta Fakultas Kedokteran dan Ilmu Kesehatan dengan empat jurusan (Keperawatan, Kesehatan Masyarakat, Farmasi dan Kebidanan). ${ }^{53}$

6. UIN Sunan Ampel Surabaya membuka tiga fakultas, yaitu Fakultas Sains dan Teknologi dengan enam jurusan (Ilmu Kelautan, Matematika, Teknik Lingkungan, Biologi, Teknik Arsitektur dan Sistem Informasi); Fakultas Psikologi dengan Jurusan Psikologi; dan Fakultas Ilmu Sosial dan Ilmu Politik dengan tiga jurusan (Ilmu Politik, Hubungan Internasional dan Sosiologi). ${ }^{54}$

7. UIN Walisongo Semarang membuka dua fakultas, yaitu Fakultas Sains dan Teknologi dengan lima jurusan (Gizi, Matematika, Kimia, Fisika dan

${ }^{50}$ Silakan akses http://uin-suka.acid/page/admisi/12, diakses pada 13 Agustus 2015.

${ }^{51}$ Silakan akses http://www.uin-malang.ac.id/s/uin/prodi, diakses pada 13 Agustus 2015.

${ }^{52}$ Silakan akses http://www.uinsgd.ac.id/front/arsip/page/kampus/info-pmb, diakses pada 13 Agustus 2015.

${ }^{53}$ Silakan akses http://uin-alauddin.ac.id/penerimaan.php, diakses pada 13 Agustus 2015.

${ }^{54}$ Silakan akses http://www.uinsby.acid/id/223/strata-1.html\#, diakses pada 20 November 2015. 
Biologi); dan Fakultas Sosial Humaniora dengan empat jurusan (Psikologi, Sosiologi, Ilmu Politik dan Ilmu Hukum). ${ }^{55}$

Dari fakultas dan program studi yang ditawarkan oleh ketujuh UIN di atas tampak bahwa studi Islam di UIN dewasa ini telah mengalami perkembangan yang sangat signifikan. Secara acak, UIN-UIN tersebut kini telah membuka fakultas-fakultas non-rumpun ilmu agama, seperti Fakultas Psikologi, Fakultas Humaniora, Fakultas Sains dan Teknologi, Fakultas Ekonomi, Fakultas Ilmu Sosial dan Ilmu Politik, Fakultas Kedokteran, dan Fakultas Ilmu Kesehatan. Pada satu sisi, perkembangan studi Islam seperti di atas tentu saja menjadi hal yang membanggakan. Keberhasilan UIN dalam mengembangkan keilmuannya dengan berbasiskan epistemologi integrasi sudah pasti didasarkan pada sifat universalitas sumber ajaran Islam.

Menurut Mulyadhi Kartanegara, ${ }^{56}$ al-Qur'an adalah buku induk ilmu pengetahuan, di mana tidak ada satu perkara apapun yang terlewatkan. Semuanya telah tercover di dalam al-Qur'an, baik yang mengatur hubungan manusia dengan Allah, hubungan manusia dengan sesama manusia, ataupun hubungan manusia dengan alam dan lingkungan. Achmad Baiquni menegaskan bahwa "Sebenarnya segala ilmu yang diperlukan manusia itu tersedia di dalam al-Qur'an."57

Dengan demikian, al-Qur'an dapat menjadi sumber inspirasi bagi lahirnya beragam ilmu pengetahuan, baik ilmu-ilmu sosial, ilmu-ilmu budaya dan humaniora, ilmu-ilmu alam, terutama ilmu-ilmu agama. Di dalam al-Qur'an, banyak sekali ditemukan ayat-ayat al-Qur'an yang menginspirasi bagi pengembangan keilmuan UIN. ${ }^{58}$ Inilah perkembangan menggembirakan dari studi Islam kontemporer di dalam kerangka keilmuan UIN, yang telah menjadikan epistemologi integrasi sebagai basis keilmuannya. PTKI, khususnya UIN, telah mampu memposisikan dirinya untuk berdiri sederajat dengan PTU.

Akan tetapi, pada sisi yang lain, UIN sejatinya telah "melampaui batas" mandat keilmuannya. Sebab, mandat keilmuan yang diamanatkan oleh UUPT 2015.

55Silakan akseshttp://www.sbmptn.or.id/index.php?mid=14\&ptn=45, diakses pada 20 November

56Mulyadhi Kartanegara, Reaktualisasi Tradisi Ilmiah Islam, (Jakarta: Baitul Ihsan, 2006), h. 119.

${ }^{57}$ Achmad Baiquni, al-Qur'an dan Ilmu Pengetahuan Kealaman, (Yogyakarta: Dana Bakhti Prima Yasa, 1997), h. 17.

${ }^{58}$ Kajian tentang ayat-ayat al-Qur'an ini, lihat misalnya Toto Suharto dan Suparmin, Ayat-Ayat alQur'an tentang Rumpun Ilmu Agama: Perspektif Epistemologi Integrasi-Interkoneksi, Cet. I, (Sukoharjo: FATABA Press, 2014), h. 64-114. 
Pasal 10 ayat (2) adalah bahwa PTKI diberi kewenangan untuk menyelenggarakan pendidikan dalam "rumpun ilmu agama" dengan tujuh wilayah fakultas keilmuan. Fakultas-fakultas non-rumpun ilmu agama yang ada di UIN, berdasarkan mandat UU PT ini, sudah pasti posisinya berada di luar mandat keilmuan UIN.

Untuk itu, agar keilmuan UIN tidak melampaui mandat keilmuannya, ilmuilmu non-rumpun ilmu agama yang ada di UIN perlu direposisi dengan menggunakan paradigma "teo-antropo-kosmosentrisme". Paradigma keilmuan untuk UIN ini dapat dimetaforakan dalam bentuk "Segitiga Ilmu". Segitiga ilmu ini penting dipahami, sebab menurut 'Abdul-Rahman Salih 'Abdullah kurikulum pendidikan Islam itu terdiri atas tiga kategori keilmuan, yaitu: (1) al-ulūm aldīniyyah, yakni ilmu-ilmu keislaman normatif yang menjadi kerangka acuan bagi segala ilmu yang ada; (2) al-ulüm al-insāniyyah, yakni ilmu-ilmu sosial dan humaniora yang berkaitan dengan manusia dan interaksinya, seperti sosiologi, antroplogi, psikologi, pendidikan dan lain-lain; dan (3) al'-ulüm al-'kawniyyah, yaitu ilmu-ilmu kealaman yang mengandung asas kepastian, seperti fisika, kimia, biologi, matematika dan lain-lain. ${ }^{59}$ Ketiga kategori keilmuan ini mengindikasikan adanya tiga paradigma keilmuan: teosentrisme, antroposentrisme dan kosmosentrisme, yang apabila diintegrasikan akan tampak dalam gambar integrasi "segitiga ilmu" dengan paradigma teo-antropo-kosmosentrisme sebagai berikut:

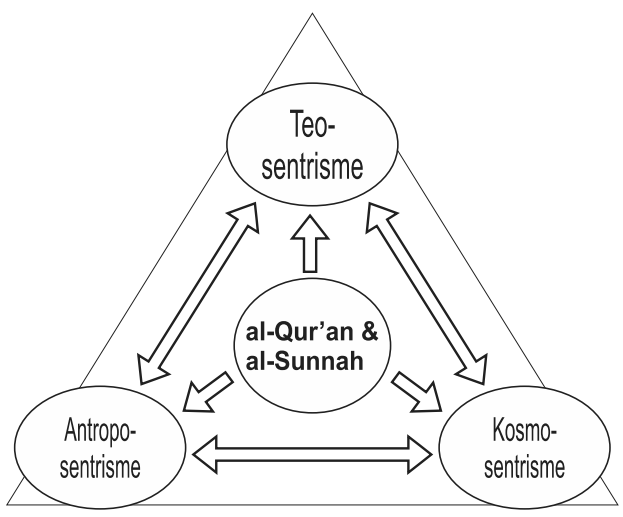

Gambar:

Integrasi "Segitiga Ilmu" dengan Paradigma Teo-antropo-kosmosentrisme

\footnotetext{
${ }^{59}$ Abdul-Rahman Salih 'Abdullah, Educational Theory: A Qur'anic Outlook, (Makkah AlMukarramah: Umm al-Qura University, t.th.), h. 138-139.
}

Walisongo, Volume 23, Nomor 2, November 2015 
Dari gambar di atas dapat diilustrasikan bahwa model integrasi "Segitiga Ilmu" bertumpu pada paradigma Teo-antropo-kosmosentrisme. Paradigma ini mencoba mengintegrasikan antara paradigma teosentrisme, antroposentrisme dan kosmosentrisme. Paradigma teosentrisme yang posisinya di atas harus menjadi core dan payung bagi dua paradigma lainnya, karena paradigma ini memuat al-'ulūm al-dīniyyah. Paradigma antroposentrisme yang memuat al'ulūm al-insāniyyah, dan paradigma kosmosentrisme yang terdiri atas al-'ulūm al-kawniyyah, harus selalu berinteraksi dengan paradigma teosentrisme, karena ini yang menjadi core bisnisnya. Ketiga paradigma senantiasa bersumber pada al-Qur'an dan Sunnah. Untuk dapat memahami al-Qur'an dan Sunnah, diperlukan metodologi dan pendekatan ilmiah yang digunakan dalam ketiga paradigma tersebut.

Itulah reposisi ilmu-ilmu non-rumpun ilmu agama dengan paradigma teoantropo-kosmosentrisme, yang terilustrasikan dalam integrasi model "Segitiga Ilmu". Dengan paradigma ini, ketika UIN membuka fakultas non-rumpun ilmu agama, baik yang antroposentris maupun yang kosmosentris, maka fakultas ini akan menjadi berbeda dangan fakultas sejenis yang ada di PTU, karena fakultas non-rumpun ilmu agama UIN tetap di bawah paradigma teosentrisme. Pada saat yang sama, fakultas non-rumpun ilmu agama UIN pun berbeda dangan PTU, karena bersumber dari sumber ajaran Islam; al-Qur'an dan Sunnah.

Manakala reposisi ini dapat dijewantahkan dalam keilmuan integrasi UIN, maka fakultas keilmuan apapun yang dibuka di UIN, pembukaan fakultas ini tidak akan "melampaui batas" mandat keilmuan PTKI, sebagaimana diamanatkan dalam UU PT. Pada saat yang sama, pembukaan fakultas ilmu-ilmu sosialhumaniora atau fakultas ilmu-ilmu kealaman apapun oleh UIN, tidak akan menjadi "kebablasan", keluar dari core bisnisnya, karena fakultas-fakultas ini berada di bawah payung ilmu-ilmu teosentrisme. Ketika ini terjadi, maka sudah dapat dipastikan UIN di Indonesia dapat melahirkan "ilmuwan yang ulama", sebagaimana era Klasik Islam. Pada masa ini, semua ilmuwan Muslim, baik ahli sosiologi, fisika, matematika atau kedokteran, mereka adalah ulama. Ini berkat paradigma teosentrisme yang menjadi payungnya.

\section{E. Kesimpulan}

Ketika UIN-UIN di Indonesia dewasa ini mengembangkan wilayah studi Islamnya dengan membuka fakultas dan program studi dalam studi ilmu-ilmu 
sosial-humaniora dan ilmu-ilmu kealaman, maka hal ini sejatinya merupakan kebanggaan bagi perkembangan studi Islam di Indonesia. Bagaimana tidak, PTKI yang dulu dikesankan menempati posisi marginal vis a vis pendidikan tinggi umum, kini dapat berdiri sederajat dengan PTU dengan diberi keluasan untuk membuka fakultas dalam ilmu-ilmu non-rumpun ilmu agama, seperti seperti fakultas psikologi, fakultas humaniora, fakultas sains dan teknologi, fakultas ekonomi, fakultas ilmu sosial dan ilmu politik, fakultas kedokteran, dan fakultas ilmu kesehatan.

Akan tetapi, dari sudut konstitusional, terutama UU Pendidikan Tinggi Pasal 10 ayat (2), kondisi di atas menjadi problem akademik-epistemologis yang patut juga diselesaikan secara akademis. UU PT ini mengamanatkan bahwa PTKI diberi mandat keilmuan untuk menyelengarakan pendidikan dalam wilayah yang disebut rumpun ilmu agama, dengan konsentrasi pada tujuh wilayah studi, yaitu: (a) Ilmu Ushuluddin, (b) Ilmu Syariah, (c) Ilmu Adab, (d) Ilmu Dakwah, (e) Ilmu Tarbiyah, (e) Filsafat dan Pemikiran Islam, (f) Ekonomi Islam. Dengan membuka fakultas dan program studi di luar rumun ilmu agama, PTKI dapat dinyatakan "melampaui batas" mandat keilmuan ini.

Untuk itu, kajian ini menawarakan penggunaan paradigma teo-antropokosmosentrisme dalam rangka mereposisi ilmu-ilmu non-rumpun ilmu agama yang sekarang dibuka di beberapa fakultas di UIN. Reposisi dilakukan dengan menajamkan model integrasi dengan metafora "Segitiga Ilmu", yang berbasiskan pada paradigma teo-antropo-kosmosentrisme. Paradigma ini mencoba mengintegrasikan antara paradigma teosentrisme, antroposentrisme dan kosmosentrisme. Paradigma teosentrisme yang posisinya di atas harus menjadi core dan payung bagi dua paradigma lainnya, karena paradigma ini memuat $a l-$ 'ulüm al-dīniyyah. Paradigma antroposentrisme yang memuat al-ulūm alinsāniyyah, dan paradigma kosmosentrisme yang terdiri atas al-ulüm alkawniyyah, harus selalu berinteraksi dengan paradigma teosentrisme, karena ini yang menjadi core bisnisnya. Ketika reposisi ini dapat dijewantahkan dalam keilmuan integrasi UIN, fakultas keilmuan apapun yang dibuka di UIN, maka fakultas ini tidak akan "melampaui batas" mandat keilmuan PTKI. Pada saat yang sama, pembukaan fakultas ilmu-ilmu sosial-humaniora atau fakultas ilmuilmu kealaman apapun oleh UIN, tidak akan menjadi "kebablasan", keluar dari core bisnisnya, karena fakultas-fakultas ini berada di bawah payung ilmu-ilmu teosentrisme.[w] 


\section{BIBLIOGRAPHY}

Abdullah, 'Abdul-Rahman Salih, Educational Theory: a Qur'anic Outlook, Makkah al-Mukarramah: Umm al-Qura University, n.d.

Abdullah, M. Amin, Falsafah Kalam di Era Postmodernisme (Philosophy of Kalam in Postmodernism Era), Yogyakarta: Pustaka Pelajar, 1997.

Abdullah, M. Amin, Islamic Studies di Perguruan Tinggi: Paradigma IntegratifInterkonektif (Islamic Studies in Higher Education: Integrative-Interconnective Paradigm), Ist Ed., Yogyakarta: Pustaka Pelajar, 2006.

Ali, A. Mukti. Metode Memahami Agama Islam (Methods to Understand Islam), Jakarta: Bulan Bintang, 1991.

Arsyad, Azhar, "Buah Cemara Integrasi dan Interkoneksitas Sains dan Ilmu Agama" (Pine Tree Fruits of Integration and Interconnection between Science and Religious Studies), Hunafa: Jurnal Studia Islamika, Vol. 8, No. 1, Juni 2011.

Azra, Azyumardi, "IAIN di Tengah Paradigma Baru Perguruan Tinggi” (IAIN in the Middle of New Paradigm of Colleges), in Komaruddin Hidayat \& Hendro Prasetyo, Problem dan Prospek IAIN: Antologi Pendidikan Tinggi Islam (Problem and Prospect of IAIN: Antology of Islamic Higher Education), Jakarta: Dirjen Binbaga Islam, 2000.

Azra, Azyumardi, "Reintegrasi Ilmu-ilmu dalam Islam" (Reintegration of Islamic Science), Zainal Abidin Bagir et.al (eds.), Integrasi Ilmu dan Agama: Interpretasi dan Aksi (Integration of Science and Religion), Bandung: Mizan, 2005.

Baiquni, Achmad, al-Qur'an dan Ilmu Pengetahuan Kealaman (al-Qur'an and Natural Science), Yogyakarta: Dana Bakhti Prima Yasa, 1997.

Fanani, Muhyar, "Paradigma Kesatuan Ilmu (Unity of Sciences) dalam Visi dan Misi IAIN Walisongo" (Paradigm in Unity of Sciences in IAIN Walisongo's Vision and Mission), presented in Powerpoint on October 30th, 2013 at Hotel Novotel, Semarang.

Fathurrahman, Oman, "Prof. Dr. Azyumardi Azra, M.A.: Mewujudkan 'Mimpi' IAIN menjadi UIN" ("Prof. Dr. Azyumardi Azra, M.A.: Realizing a "Dream" 
of Transforming the State Institute for Islamic Studies toward State Islamic University) in Badri Yatim \& Hamid Nasuhi (eds.), Membangun Pusat Keunggulan Studi Islam (Building a Center of Excellence for Islamic Studies), Jakarta: IAIN Jakarta Press, 2002.

Hanafi, Hanafi, Dirasat Islämiyyah (Islamic Studies), n.p: Maktabah al-Anglo alMishriyyah, n.d.

Idi, Abdullah dan Toto Suharto, Revitalisasi Pendidikan Islam (Revitalization of Islamic Education), Yogyakarta: Tiara Wacana, 2006.

Taufiq, Imam, "Komitmen Kebangsaan IAIN" (Nationality Commitment of IAIN), Suara Merdeka, April 7th, 2014.

Kartanegara, Mulyadhi, Menembus Batas Waktu: Panorama Filsafat Islam (Going Beyond Time: Panorama of Islamic Philosophy), Bandung: Mizan, 2002.

Kartanegara, Mulyadhi, Reaktualisasi Tradisi Ilmiah Islam (Reactualization of Islamic Scientific Tradition), Jakarta: Baitul Ihsan, 2006.

Maarif, A. Syafii, Islam: Kekuatan Doktrin dan Kegamangan Umat (slam: The Strength of Doctrine and the Dizziness of Muslim Society)., Yogyakarta Pustaka Pelajar, 1997.

Maarif, A. Syafii, Peta Bumi Intelektualisme Islam di Indonesia (World Map of Islamic Intellectualism in Indonesia), Bandung: Mizan 1993.

Mahkamah Konstitusi, Membangun Demokrasi Substantif, Meneguhkan Integritas Institusi: Laporan Tahunan 2010 (Building Substantive Democracy, Strengthening Institutional Integrity: Yearly Report 2010), Jakarta: Sekretariat Jenderal dan Kepaniteraan Mahkamah Konstitusi, 2010.

Natsir, Nanat Fatah, "Merumuskan Landasan Epistemologi Pengintegrasian Ilmu Qur'aniyyah dan Kawniyyah" (Formulating the basic Epistemology of Integrating the Qur'aniyah and Kawniyyah Sciences) in Tim Editor (eds.), Pandangan Keilmuan UIN: Wahyu Memandu Ilmu (Scientific Outlook of UIN: Revelation Guiding Sciences), Bandung: Gunung Djati Press, 2006.

Panja RUU Pendidikan Tinggi Komisi X DPR RI, "Kerangka Acuan Kunjungan Kerja Panja Komisi X DPR RI dalam Rangka Masukan terhadap RUU tentang Pendidikan Tinggi ke Universitas Hasanuddin, Universitas Brawijaya dan Universitas Lambung Mangkurat" (Terms of Reference for 
the Working Visit by Commission X of Indonesian Parliament in the Framework of Giving Feedback to the Draft of Law on Higher Education to Hasanuddin University, Brawijaya University, and Lambung Mangkurat University), 2012.

RUU Pendidikan Tinggi Hasil Panitia Kerja RUU DIKTI (Draft Law on Higher Education), for Public Testing Materials, February 22th, 2012.

RUU Pendidikan Tinggi Hasil Panitia Kerja RUU DIKTI (Draft Law on Higher Education), April 4th, 2012.

Suharto, Toto dan Khuriyah, "The Scientific Viewpoint in State Islamic University in Indonesia", Jurnal Pendidikan Islam, Vol. 1, No. 1, June 2014 M/1435 H.

Suharto, Toto dan Suparmin, Ayat-ayat al-Qur'an tentang Rumpun Ilmu Agama: Perspektif Epistemologi Integrasi-Interkoneksi (Qur'anic Verses on the Clusters of Religious Sciences: Perspective of Integration-Interconnection Epistemology). Sukoharjo: FATABA Press, 2014.

Suharto, Toto, "Studi Islam di Era Multikultural: Respons UIN terhadap Kebijakan Rumpun Ilmu Agama" (Islamic Studies in Multicultural Era: UIN's Response oward the Policy on the Clusters of Islamic Studies), Paper, presented 14th Annual International Conference on Islamic Studies (AICIS), di Grand Senyiur Hotel, Balikpapan, November 21-24th, 2014.

Suharto, Toto, "Tren Baru Studi Islam di Indonesia: Menuju Teo-antroposentrisme (New Trend of Islamic Studies in Indonesia: Leading to TheoAntropocentrism) in Toto Suharto \& Nor Huda (eds.), Arah Baru Studi Islam di Indonesia: Teori dan Metodologi (New Directions of Islamic Studies in Indonesia: Theory and Methodology), Yogyakarta: Ar-Ruzz Media, 2008.

Suprayogo, Imam, Paradigma Pengembangan Keilmuan Islam Perspektif UIN Malang (he Paradigm for Developing Islamic Sciences in the Perspective of UIN Malang), Malang: UIN-Malang Press, 2006.

Tim UIN Sunan Ampel Surabaya. Desain Akademik UIN Sunan Ampel Surabaya: Buiding Character Qualities for the Smart, Pious and Honourable Nation (Academic Design of UIN Sunan Ampel Surabaya: Buiding Character Qualities for the Smart, Pious and Honourable Nation). 2nd Ed., Surabaya: UINSA Press, 2015.

Tsuwaibah, "Epistemologi Unity of Science Ibn Sina: Kajian Integrasi Keilmuan Ibn Sina dalam Kitab Asy-Syifa Juz I dan Relevansinya dengan Unity of Science 
IAIN Walisongo, (Epistemology of Ibn Sina's Thought on Unity of Science: the Study of Unity of Science in Kitāb al-Șifā')", Personal Research Report, IAIN Walisongo Semarang, 2014.

Undang-Undang RI No. 12 Tahun 2012 tentang Pendidikan Tinggi. (Constitution of Republic of Indonesia No. 12 Year 2012 about Higher Education).

\section{Internet:}

Editors Team, "Core Values" http://uin-suka.ac.id/index.php/page/ universitas/29-core-values, accessed on December 12th, 2013.

Editors Team, "Paradigma Keilmuan" (The Paradigm of Science), http://www. uinsby.ac.id/id/251/paradigma-keilmuan.html, accessed on November 20th, 2015.

Editors Team, "Sekilas UIN Sunan Kalijaga" (A Snapshot of UIN Sunan Kalijaga), http://www.uin-suka.ac.id/id/about/universitas-1-sekilas-uin.htmlaccessed on June 12th, 2011.

Editors Team, "Struktur Keilmuan" (Structure of Science), http://www.uinmalang.ac.id/index.php?option=com_content\&view=article\&id=7:strukturkeilmuan\&catid=1:pendahuluan\&Itemid=144 - accessed on December 10th, 2013.

Editors Team, "Visi, Misi dan Tagline" (Vision, Mission, and Tagline), http://www.uinsby.ac.id/id/185/visi-misi-dan-tagline.html, accessed on November 20th, 2015

Hiqmah, Luthfiyatul, "Wahdatul Ulum sebagai Konsep Integrasi Islam dan Sains di UIN Walisongo" ("Unity of Science as the Concept on Integration of Islam and Sciences in UIN Walisongo), http://hiqmah12.blogspot.co.id/ 2014/05/wahdatul-ulum-sebagai-konsep-integrasi.html - accessed on November 20th, 2015.

http://uin-alauddin.ac.id/penerimaan.php - accessed on August 13th, 2015.

http://uinjkt.acid/id/akademik/program-sarjana - accessed on August 13th, 2015.

http://uin-suka.ac.id/page/admisi/12 - accessed on August 13th, 2015. 
http://www.uin-malang.ac.id/s/uin/prodi - accessed on August 13th, 2015. http://www.uinsgd.ac.id/front/arsip/page/kampus/info-pmb - accessed on August 13th, 2015.

Luknanto, Djoko, "UU RI No. 12 Tahun 2012 tentang Pendidikan Tinggi" (Constitution of RI No. 12 Year 2012 about Higher Education), http://luk.tsipil.ugm.ac.id/atur/UU12-2012/ - accessed on May 25th, 2013.

Marlinawati, Reni, "Jauh Panggang dari Api: Rancangan Undang-Undang Pendidikan Tinggi" (A Far Cry from the Reality: Constitution Layout of Higher Education), posted Februari 6th 2012, http://fppp.or.id/web/ berita/1020\#. UUSxNDqxlYw - accessed on May 24th, 2013.

Syam, Nur, "Model Twin Towers untuk Islamic Studies" (Model of Twin Towers for Islamic Studies), http://nursyam.uinsby.ac.id/?p=762 - accessed on November 20th, 2015. 